\title{
Direct Determination of Arsenic and Chromium in Seawater Samples Using On-Line Dilution and ICP-MS Analysis
}

\author{
María Carmen Barciela-Alonso, Marta Castrelo Otero, María Raquel Domínguez González, \\ Elena Peña-Vázquez, Pilar Bermejo-Barrera* \\ Deparment of Analytical Chemistry, Nutrition and Bromatology, \\ Faculty of Chemistry. University of Santiago de Compostela \\ Avenida das Ciencias s/n, 15782 Santiago de Compostela. Spain
}

\section{INTRODUCTION}

Arsenic (As) and chromium (Cr) are toxic elements and widely distributed in the environment. They are present in seawater from natural and anthropogenic sources due to the different industrial applications in which these elements are used. Arsenic compounds, for instance, are used for the production of insecticides and herbicides, and as additives for animal feed and wood preservatives (1). Anthropogenic chromium discharges from industrial procedures such as plating and tanning, and from solutions for glassware cleaning and wood preservation $(2,3)$. Once these elements are released into the ocean, they are ingested by aquatic life and then become part of the food chain by polluting marine animals used for human consumption leading to health problems. With the aim to maintain safe quality aquatic ecosystems, the Directive 2000/60/EC of the European Parliament and of the Council of 23 October 2000 established a framework for community action in the field of water policy (4). Similarly, the Spanish Law of 9/2010 of the Galician Waters (5) established quality objectives for the Galician estuaries as well as the allowable limits of emission for different elements in wastewater. As reported in the liteerature, the total As and Cr concentrations in clean coastal waters are between $1-3 \mu \mathrm{g} \mathrm{L}^{-1}$ and 0.04-10.8 $\mu \mathrm{g} \mathrm{L}^{-1}$, respectively $(6,7)$.

\footnotetext{
*Corresponding author.

E-mail: pilar.bermejo@usc.es

Tel.: +34881814266

Fax: +34981547141
}

\section{ABSTRACT}

A method for total As and $\mathrm{Cr}$ determination in seawater samples has been developed. As and Cr were measured using the seaFAST2 automated sample introduction system coupled to an ICP-MS. The sampling system allows on-line sample dilution (10 times) before introduction into the ICP-MS.

Calibration was performed using the standard addition method, working in the concentration range of 0 to $50 \mu \mathrm{g} \mathrm{L}^{-1}$ for As and 0 to $25 \mu \mathrm{g} \mathrm{L}^{-1}$ for $\mathrm{Cr}$. The method shows good sensitivity resulting in LODs and LOQs of 0.3 and $0.9 \mu \mathrm{g} \mathrm{L}^{-1}$, respectively, for As and of 0.03 and 0.09 , respectively, for $\mathrm{Cr}$ determination. The method was precise (RSD $<2 \%$ ) and accurate.

This method was applied to the determination of As and Cr in different seawater samples from the Galician coast of Spain. The concentrations found ranged from 0.3 to $3.1 \mu \mathrm{g} \mathrm{L}^{-1}$ for As and from 0.03 to $0.1 \mu \mathrm{g} \mathrm{L}^{-1}$ for $\mathrm{Cr}$.

Various studies have reported on the As and $\mathrm{Cr}$ determination in seawater samples. The main problem with this type of analysis is the very low concentrations of these metals in the samples (on the order of ng $\mathrm{L}^{-1}$ to a few $\mu \mathrm{g} \mathrm{L^{-1 }}$ levels). In addition, there is the problem of salinity of the samples, which can produce interferences in the analysis. Some of the methods used to overcome these limitations with preconcentration steps are the use of chelating resins (8-11), knotted reactors $(12,13)$, and co-precipitation with magnesium hydroxide $(14,15)$. Dif- ferent detection systems have been used for their determination, including electrothermal atomic absorption spectrometry (ETAAS) $(12,13,16)$, atomic fluorescence spectrometry (AFS) $(7,17)$, total reflection X-ray fluorescence spectrometry $(18,19)$, and inductively coupled plasma mass spectrometry (ICP-MS) (10, 11, 14, 15, 20-23). ICP-MS offers a number of advantages over other detection systems, such as sensitivity and the possibility of multielemental analysis.

The aim of this work was to develop a simple and fast method for the As and Cr determination in seawater samples obtained from the Galician coast (northwestern Spain) by ICP-MS using the seaFAST2 system for on-line sample preparation.

\section{EXPERIMENTAL}

\section{Instrumentation}

For this study, a model NexION® 300X inductively coupled plasma mass spectrometer (PerkinElmer, Shelton, CT, USA) was used, equipped with a collision cell. The instrumental operating parameters are listed in Table I. To minimize polyatomic interferences, He was used as the collision gas for As and Cr determination. The SeaFAST2 preconcentrtion system (Elemental Scientific, Inc., USA) was coupled to the ICP-MS for the automatic dilution of seawater samples (10 times) for total As and $\mathrm{Cr}$ determination (24). The system includes one peristaltic pump, three valves, two columns for cleanup of the carrier and buffer, and one column for preconcentration of the elements. The 
peristaltic pump propels the reagents at $6 \mathrm{rpm}$ with tubes of different internal diameters $(1.14 \mathrm{~mm}$ for the carrier, $0.76 \mathrm{~mm}$ for the buffer, 0.13 and $0.38 \mathrm{~mm}$ for the eluent, and $1.3 \mathrm{~mm}$ for waste). The seaFAST2 system can operate in two different modes: the direct mode of analysis, which enables on-line dilution and addition of an internal standard, and the preconcentration mode. A schematic diagram of the seaFAST2 system is shown in Figure 1.

\section{Standard Solutions and Reagents}

Ultrapure water of $18 \mathrm{M} \Omega \cdot \mathrm{cm}$, obtained from a Milli-Q ${ }^{\circledR}$ water purification system (Millipore Corportion. Bedford, MA, USA), was used throughout the work.

A stock standard solution of As (1000 $\mathrm{mg} \mathrm{L}^{-1}$ ) was purchased from Fluka (Switzerland), while the stock standard solution of $\mathrm{Cr}\left(1000 \mathrm{mg} \mathrm{L}^{-1}\right)$ and $\mathrm{Cr}\left(\mathrm{NO}_{3}\right)_{3}$ in $0.5 \mathrm{M} \mathrm{HNO}_{3}$ was obtained from Scharlau (Barcelona, Spain). All standard solutions were prepared by dissolving the corresponding amount of salt in ultrapure water. Nitric acid of $69 \%$ Hiperpur-Plus was obtained from Sigma-Aldrich, USA. The internal standards used were Rh (1000 $\mathrm{mg} \mathrm{L}^{-1}$,

TABLE I ICP-MS Instrumental Operating Conditions

$\begin{array}{ll}\text { Plasma gas flow } & 18 \mathrm{~L} \mathrm{~min}^{-1} \\ \text { Auxiliary gas flow } & 1.2 \mathrm{Lmin}^{-1} \\ \text { Aerosol carrier } & 0.83 \mathrm{Lmin}^{-1} \\ \text { Plasma power } & 1600 \mathrm{~W} \\ \text { Monitored signal } & { }^{75} \mathrm{As},{ }^{52} \mathrm{Cr},{ }^{53} \mathrm{Cr} \\ \text { Scan mode } & \text { Peak hopping } \\ \text { Dwell time } & 115 \mathrm{~ms} \\ \text { Integration time } & 4600 \mathrm{~ms} \\ \text { CCT-KED He } & 4 \mathrm{~mL} \mathrm{~min}{ }^{-1} \\ \text { RPq } & 0.25 \\ \text { Sweeps/reading } & 20 \\ \text { Readings/replicate } & 2 \\ \text { Replicates } & 3\end{array}$

Fluka, Switzerland) and Y (1000 $\mathrm{mg} \mathrm{L}^{-1}$, Panreac, Spain) for the total As and Cr determination by ICP-MS.

To verify the accuracy of the method, the certified reference material NASS-4 Ocean Seawater (National Research Council Canada) was used.

\section{Sample Preparation}

Nine samples of surface seawater were collected from different areas along the Galician coast of northwestern Spain. These are identified in Figure 2 and are listed as Vilanova de Arousa, Esteiro, Pontevedra, Marín, Cambados, Bouzas, Canido, Vilagarcía de Arousa and Portosin. The samples (1 L) were collected in pre-cleaned $2.5 \mathrm{~L}$ nonmetallic free-flushing Niskin bottles. After collection, the samples were filtered $(0.45 \mu \mathrm{m})$ and immediately stored in polyethylene bottles at $-20{ }^{\circ} \mathrm{C}$ until analysis.

\section{ICP-MS Determination of As and $\mathrm{Cr}$}

Total As and Cr determination was performed by ICP-MS. Both elements were quantified by means of the multielemental standard additions method ranging from $0-50$ $\mu \mathrm{g} \mathrm{L^{-1 }}$ and $0-25 \mu \mathrm{g} \mathrm{L}^{-1}$ for As and $\mathrm{Cr}$, respectively. Internal standards of ${ }^{103} \mathrm{Rh}$ and ${ }^{89} \mathrm{Y}$ were used to correct possible matrix effects and signal drift. A $10 \mu \mathrm{g} \mathrm{L}^{-1}$ solution of the internal standards in $7.3 \% \mathrm{HNO}_{3}$ was mixed with the sample in the seaFAST2 system.

\section{RESULTS AND DISCUSSION}

Total As and $\mathrm{Cr}$ determination was performed using the seaFAST2 coupled to ICP-MS. The seaFAST2 is a completely automated introduction system for multi-mode determination of ultra-trace metals in undiluted seawater samples.

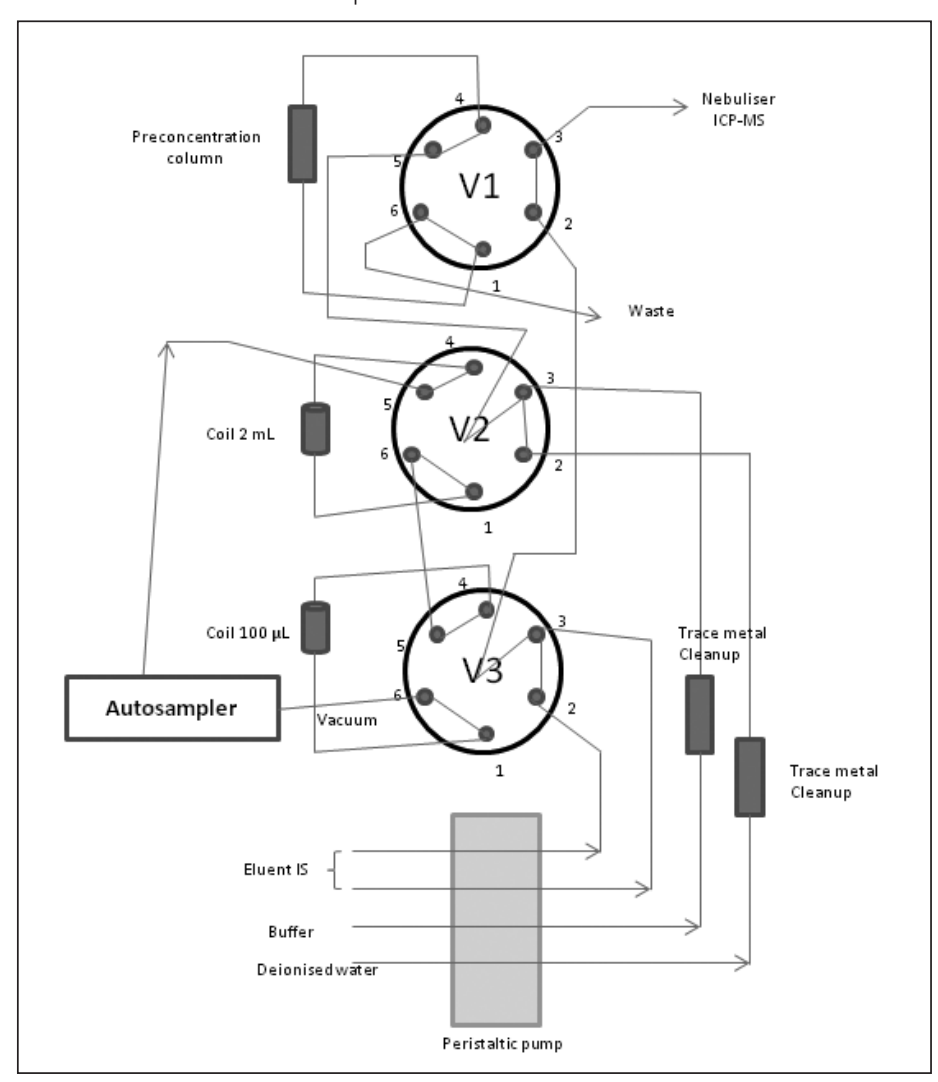

Fig. 1. Schematic diagram of seaFAST2 System. 
This system allows the on-line sample dilution (10 times) before its introduction into the ICP-MS. Sample dilution was performed using $7 \% \mathrm{HNO}_{3}$ Hiperpur-plus (69\%) containing internal standards (10 $\mu \mathrm{g} \mathrm{L}^{-1} \mathrm{Rh}$ and $\mathrm{Y}$ ). For better results, the measurements were performed using the standard and KED mode (Kinetic Energy Discrimination) with $\mathrm{He}$ as the collision gas.

\section{Calibration and Analyte Addition Graphs}

First, experiments were performed to compare the slopes of the calibration and addition graphs. Calibration was performed using aqueous standards at As concentrations of $0,5,10,20,30,40$, and 50 $\mu \mathrm{g} \mathrm{L}^{-1}$ and at $\mathrm{Cr}$ concentrations of $0,2,5,10,15,20$, and $25 \mu \mathrm{g} \mathrm{L}^{-1}$.

The standard addition method was also used in the same range of concentrations using a pool of seawater samples. For Cr determination, the ${ }^{52} \mathrm{Cr}$ and ${ }^{53} \mathrm{Cr}$ isotopes were measured. Analysis was performed with (KED mode) and without (standard mode) He as the collision gas. When analysis were performed in the standard mode, better results were obtained for the ${ }^{52} \mathrm{Cr}$ isotope, most likely due to polyatomic interferences. In the presence of chloride, various interferences appear for ${ }^{53} \mathrm{Cr}$ such as, ${ }^{37} \mathrm{Cl}^{16} \mathrm{O}^{+}$, ${ }^{35} \mathrm{Cl}^{17} \mathrm{O}^{1} \mathrm{H}^{+},{ }^{3} 5 \mathrm{Cl}^{18} \mathrm{O}^{+}$(24). The use of $\mathrm{He}$ as the collision gas (KED mode) improved the results for both elements and for both isotopes

TABLE II

Slopes and Correlation Coefficients Obtained for Calibration and Standard Addition Graphs

\begin{tabular}{ccc|cc}
\hline & \multicolumn{2}{c|}{ Aqueous Calibration } & \multicolumn{2}{c}{ Standard Addition Calibration } \\
\hline & Slope & $\begin{array}{c}\text { Correlation } \\
\text { Coefficient }\end{array}$ & Slope & $\begin{array}{c}\text { Correlation } \\
\text { Coefficient }\end{array}$ \\
\hline As & 21.3 & 1.000 & 10.456 & 0.9995 \\
$\mathrm{Cr}$ & 216.8 & 0.999 & 123.58 & 0.9992 \\
\hline
\end{tabular}

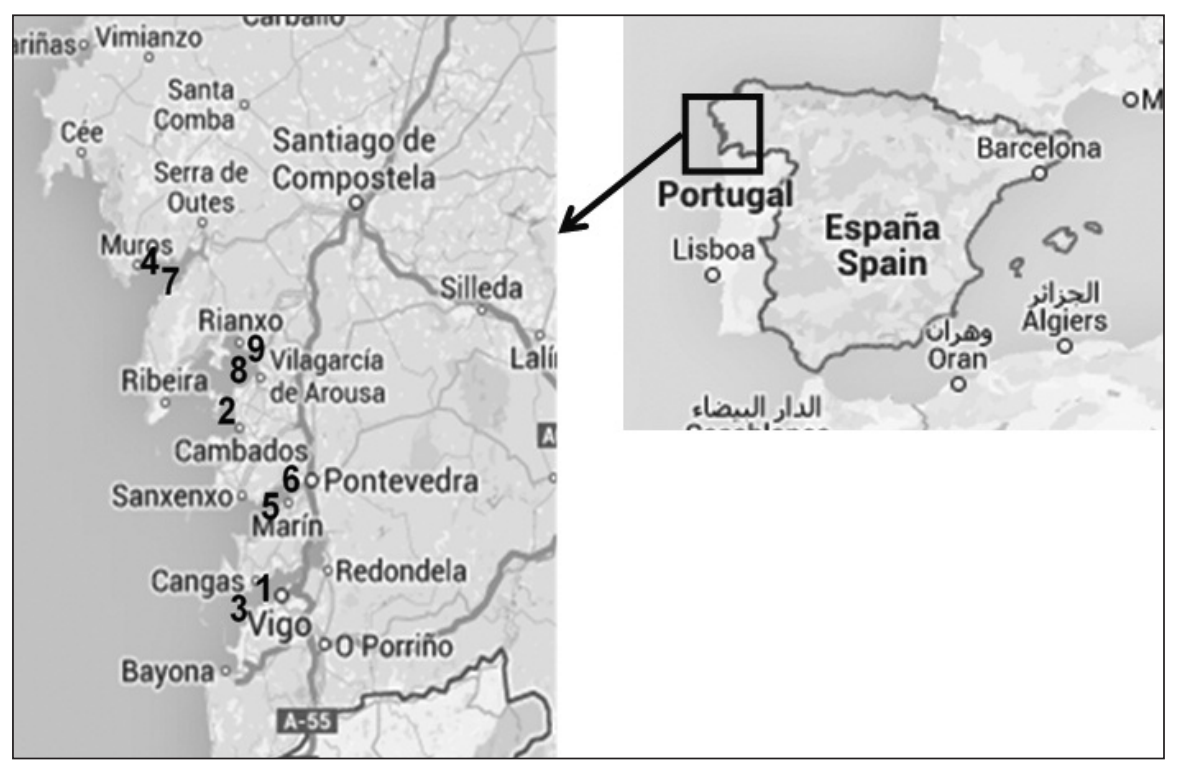

Fig. 2. Sampling points on Galician coast in Spain.

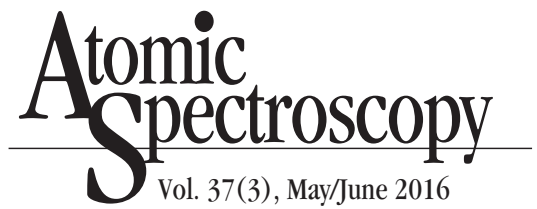

of Cr. Nevertheless, the sensitivity obtained using ${ }^{52} \mathrm{Cr}$ was higher than ${ }^{53} \mathrm{Cr}$, thus ${ }^{52} \mathrm{Cr}$ was selected for the Cr determination.

The slopes as well as the correlation coefficients ( $r$ ) obtained for the calibration and the standard addition graphs are shown in Table II. Both the calibration and the standard addition graphs show good linearity, with correlation coefficients higher than 0.995 for each element studied. The correction using internal standards did not improve the results. After statistical comparison of the slopes of the aqueous calibration and the standard addition graph by applying the Student's $t$-test (95\% significant level) (25), statistical differences were observed for both elements. Taking these results into account, the standard addition method was selected to perform this study. The correction using internal standards was not necessary to perform the analysis.

\section{Sensitivity}

The limit of detection and quantification was calculated according to $\mathrm{LOD}=(3 \mathrm{SD}) / \mathrm{m}$ and $\mathrm{LOQ}=$ $(10 S D) / m$, where SD is the standard deviation of 11 measurements of a blank and $\mathrm{m}$ is the slope of the addition graph. The LOD and LOQ values were 0.3 and $0.9 \mu \mathrm{g} \mathrm{L}^{-1}$, respectively, for As determination and 29.3 and $97.1 \mathrm{ng} \mathrm{L}^{-1}$, respectively, for $\mathrm{Cr}$ determination. A comparison of the LOD obtained for $\mathrm{Cr}$ in this study shows that it is lower than the values reported by Nicolai et al. (9) (66 ng L $\left.{ }^{-1}\right)$ using ICP-MS, with on-line preconcentration and matrix elimination with a chelating resin, and also by Sánchez et al. (11) reporting $0.530 \mu \mathrm{g} \mathrm{L}^{-1}$ for $\mathrm{Cr}$ using ICP-MS and on-line solidphase chelation.

\section{Precision and Accuracy}

The precision of the method was evaluated by studying the repeatability (within-run precision). Within-run precision was calculated 
by analyzing (10 times) a seawater sample with 1.2 and $0.7 \mu \mathrm{g} \mathrm{L}^{-1}$ of As and $\mathrm{Cr}$, respectively. The relative standard deviations obtained were $8 \%$ and $2 \%$ for As and $\mathrm{Cr}$, respectively. The results are shown in Figure 3.

To study the accuracy of the method, certified reference material NASS-4 Ocean Seawater with certified As and Cr concentrations of $1.26 \pm 0.09 \mu \mathrm{g} \mathrm{L}^{-1}$ and $0.115 \pm 0.010 \mu \mathrm{g} \mathrm{L}^{-1}$, respectively, was analyzed. The experimental As and $\mathrm{Cr}$ concentrations obtained were $1.28 \pm 0.05 \mu \mathrm{g} \mathrm{L}^{-1}$ and $0.111 \pm 0.018 \mu \mathrm{g} \mathrm{L}^{-1}$. These concentrations were compared with the certified concentrations using the Student's $t$-test (95\% significance) (26). No statistical differences were observed between both concentrations; thus, the method is accurate for As and Cr determination.

Analytical recovery was assessed at four concentration levels. A sea-

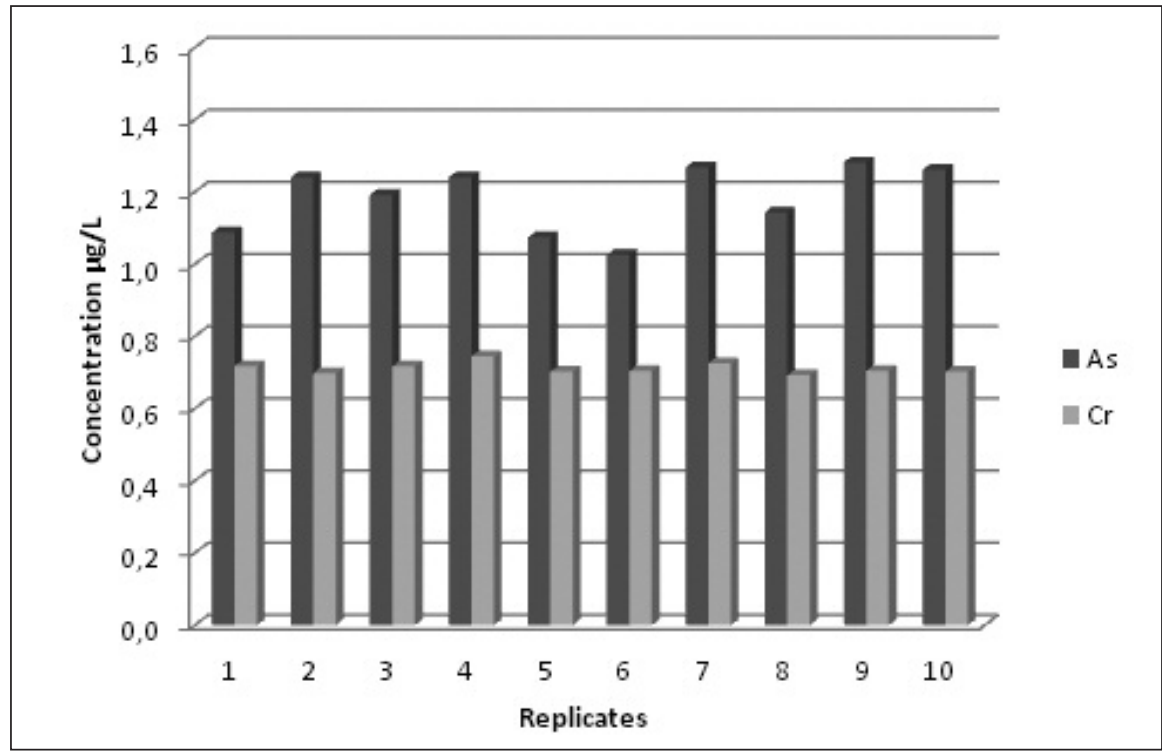

Fig. 3. Study of repeatability of the method for As and Cr determination in a seawater samples.

TABLE III

Concentration $\left(\mu \mathrm{g} \mathrm{L}^{-1}\right)$ of Total As and $\mathrm{Cr}$ and Arsenic Species in Different Seawater Samples

\begin{tabular}{llll}
\hline $\begin{array}{l}\text { Sampling } \\
\text { Point }\end{array}$ & No. & $\begin{array}{c}\text { As } \\
\left(\mu \mathrm{g} \mathrm{L}^{-1}\right)\end{array}$ & $\begin{array}{c}\mathrm{Cr} \\
\left(\mu \mathrm{g} \mathrm{L}^{-1}\right)\end{array}$ \\
\hline Bouzas & 1 & $1.8 \pm 0.03$ & $<\mathrm{LOD}$ \\
Cambados & 2 & $2.5 \pm 0.2$ & $0.04 \pm 0.0001$ \\
Canido & 3 & $1.1 \pm 0.2$ & $<\mathrm{LOD}$ \\
Esteiro & 4 & $2.9 \pm 0.06$ & $0.08 \pm 0.03$ \\
Marín & 5 & $1.5 \pm 0.04$ & $<\mathrm{LOD}$ \\
Pontevedra & 6 & $<\mathrm{LOD}$ & $<\mathrm{LOD}$ \\
Portosín & 7 & $1.8 \pm 0.07$ & $<\mathrm{LOD}$ \\
Vilagarcía de Arousa & 8 & $3.1 \pm 0.07$ & $0.1 \pm 0.02$ \\
Vilanova de Arousa & 9 & $2.4 \pm 0.05$ & $<\mathrm{LOD}$ \\
\hline LOD & & 0.3 & 0.03 \\
\hline
\end{tabular}

water sample was spiked with 5 , 20, 40 and $50 \mu \mathrm{g} \mathrm{L}^{-1}$ of As and 2, 10, 20 and $25 \mu \mathrm{g} \mathrm{L}^{-1}$ of $\mathrm{Cr}$. The analytical recoveries obtained were $93 \pm 4 \%$ and $96 \pm 4 \%$ for As and $\mathrm{Cr}$, respectively.

\section{Application of the Method}

The developed method was applied for As and $\mathrm{Cr}$ determination in nine seawater samples from the Galician Coast. Surface seawater samples $(1 \mathrm{~L})$ were collected in precleaned $2.5 \mathrm{~L}$ non-metallic freeflushing Niskin bottles. After collection, the seawater samples were filtered $(0.45 \mu \mathrm{m})$ and immediately stored in a polyethylene bottle at $-20{ }^{\circ} \mathrm{C}$ until analysis.

Samples were analyzed in triplicate using the method described above. As and $\mathrm{Cr}$ were determined using the standard addition method, using a pool of seawater samples, in the concentration ranges from $0-50 \mu \mathrm{g} \mathrm{L}^{-1}$ and $0-25$ $\mu \mathrm{g} \mathrm{L}^{-1}$, respectively. The results obtained are shown in Table III. As can be seen, the As and Cr concentrations were not detected in the sample collected in Pontevedra. The As concentrations varied from 1.1 to $3.1 \mu \mathrm{g} \mathrm{L}^{-1}$ and the highest concentration was found in Vilagarcía de Arousa, followed by Vilanova de Arousa and Esteiro. Cr was only detected in three of the samples analyzed (Cambados, Esteiro, and Vilagarcía de Arousa) with concentrations ranging from 0.04 to 0.1 $\mu \mathrm{g} \mathrm{L}^{-1}$. In general, the As and $\mathrm{Cr}$ concentrations obtained in the samples analyzed in this study are within the levels reported in the literature for seawater (26-28) and are lower than the limits established by the Spanish Law of 9/20/10 of Galician Waters.

\section{CONCLUSION}

A simple, precise ( $\mathrm{RSD}<2 \%$ ), sensitive, and accurate method for total As and $\mathrm{Cr}$ determination using the SeaFAST2 automated sample 
introduction system coupled with ICP-MS was developed. The seaFAST2 system allows on-line sample dilution (10 times) before introduction into the ICP-MS. This system minimizes the risk of sample contamination and reduces the time needed for sample preparation. Because of the influence of the sample matrix, calibration using the standard addition method was used for the determination of both elements. The use of internal standards (Y and $\mathrm{Rh}$ ) did not improve the analytical performance.

The proposed method was successfully applied to the determination of As and $\mathrm{Cr}$ in nine seawater samples from the Galician coast and obtaining concentrations lower than 3.1 and $0.1 \mu \mathrm{g} \mathrm{L}^{-1}$ for As and $\mathrm{Cr}$, respectively. These values are lower than the limits as established by the Spanish Law of 9/20/10 of Galician Waters.

\section{ACKNOWLEDGMENT}

The authors wish to thank the Ministerio de Economía y Competitividad (Project number CTQ201238901-C02-02) and Xunta de Galicia (Grupo de Referencia Competitiva 6RC2014/2016) for financial support.

Received October 14,2015.

\section{REFERENCES}

1 . P. Bermejo-Barrera, M.C. BarcielaAlonso, M. Ferrón-Novais and A. Bermejo-barrera, J. Anal. At. Spectrom. 10, 247 (1995).

2. D.G. Barceloux, J. Toxicol. Clin. Toxicol. 37(2), 173 (1999).

3. M.E. Losi, C. Amrhein, and W.T. Frankenberger, Rev. Environ. Cont. and Toxicol. 136, 91 (1994).

4. Directive 2000/60/CE, of European Parliament and of the Council of 23 October 2000 to establish a framework for Community actions in the field of water policy, Diario Oficial de las Comunidades Euro- peas, Section 1, 327 (2000).

5. Law 9/2010, 4 November, Galician Waters. BOE, 3 December 2010, Section 1, 100640.

6. Sadiq Muhammad, Toxic metal chemistry in marine environments, Marcel Dekker, Inc., New York, NY, USA (1992).

7. C.L.T. Correia, R.A. Gonçalves, M.S. Azevedo, M.A. Vieira, and R.C. Campos, Microchem. J. 96, 157 (2010).

8. S. Sahan, S. Saçmaci, S. Kartal, M Saçmaci, U. Sahim, and A. Ülguen, Talanta 85, 582 (2011).

9 . M. Nicolaï, C. Rosin, N. Tousset, and Y. Nicolai, Talanta 50, 433 (1999).

10. L. Yang, S. Willie, and R.E. Sturgeon, J. Anal. At. Spectrom. 24, 958, (2009)

11 . I. Sánchez Trujillo, E. Varela Alonso, M.T. Siles Cordero, J.M. Cano Pavón, and A. Garcia de Torres, J. Anal. At. Spectrom. 25, 1063 (2010).

12 . P. Herbello-Hermelo, M.C. BarcielaAlonso, and P. Bermejo-Barrera, At.c Spectrosc. 32(1) 27 (2011).

13 . P. Herbello-Hermelo, M.C. BarcielaAlonso, A. Bermejo-Barrera, and P. Bermejo-Barrera, J. Anal. At. Spectrom. 20, 662 (2005).

14. F. Ardini, E. Magi, and M. Grotti, Anal. Chim Acta 706, 84-(2011).

15. N. Freslon, G. Bayon, D. Birot, C. Bollinger, and J.A. Barrat, Talanta 85, 582 (2011).

16 . J. Yves Cabon, Fresenius J. Anal Chem. 367, 714 (2000)

17 . J. Wang, R.H. Liu, P. Yu, A.K. Tang, L.Q., Xu, and J.Y. Wang, Proced. Environmental Sciences 13, 1507 (2012).

18 . A.C.M Costa, M.J. Anjos, R.T. Lopes, C.A. Pérez, and C.R.F. Castro, X-ray Spetrom. 34, 183 (2005).

19. M.M. Costa, M.A. Barreiros, M.L. Carvalho, and I. Queralt, X-ray Spetrom. 28, 410 (1999).

20. M.P. Field, M. LaVigne, K.R. Murphy, G.M. Ruiz, and R.M. Sherrell, J. Anal. At. Spectrom. 22, 1145, (2007)

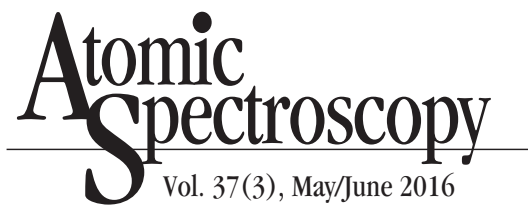

21. M. Grotti and R. Frache, J. Anal. At. Spectrom. 22, 1481 (2007).

22 . T-Y Ho, C-T Chien, B-N Wang, and A. Siriak, Talanta 82, 1478, (2010).

23 . L. Yang, S. Willie, and R.E. Sturgeon, J. Anal. At. Spectrom. 24, 158 (2009).

24. Seafast, http://www.perkinelmericpms. com/files/elan-seaFAST.pdf Last visited: 12/30/2015

25. T.W. May and R.H. Wiedmeyer. At. Spectrosc. 19(5) 150-155 (1998).

26. J.C. Millar and J.N. Millar, Statistic for Analytical Chemistry, New York, NY: Ellis Horwood, ed. (1993).

27 . I. Sánchez Trujillo, E. Vereda Alonso, A. García de Torres, and J.M. Cano Pavón, Microchem. J. 101, 87 (2012).

28 . T.R. Crompton, Toxicants in aqueous ecosystems, John Wiley \& Sons, Chichester, UK. (1997).

29. R.W. Furness and P.S. Rainbow, Heavy metals in the Marine Environment, CRC Press, Boca Raton, FL, USA (1990). 